\title{
Physical Disability in Old Kingdom Tomb Scenes
}

\author{
By Heba Mahran* \\ Samar Mostafa Kamal ${ }^{\dagger}$
}

The ancient Egyptian figural art contributed to understand some aspects of Egyptian cultural heritage never treated in the inscriptional material. Egyptian art adopted certain rules among which were the representation of the kings and tomb owners in an idealistic body. This was not the same case when dealing with minor figures. This was probably responsible for depicting some of these figures with actual disabilities and deformities. This expressed cultural and social acceptance of the disabled which was supported by wisdom writings and moral teachings.

This article aims to be an analytical and a descriptive study of the representation modes related to physical disability in Old Kingdom tomb scenes, their different types of portrayal and interpretations. The paper would also discuss the functions of deformed individuals and specific roles in the Egyptian society based on examining a group of Old Kingdom tomb scenes.

\section{Introduction}

Disability has been often defined as physical, mental or psychological conditions that limit a person's activities. ${ }^{1}$ Disability can be divided into a number of broad sub-categories, which include the following: mobility and physical impairments, Spinal Cord Disability, Brain Disability, Vision Disability, Hearing Disability, Cognitive or Learning Disabilities and Psychological Disorders. ${ }^{2}$

In ancient Egypt physical disabilities or body deformities were considered as divine attributes granted to humans by the gods. This was expressed in representing certain gods with misshapen bodies or as dwarfs, like god Bes, Hapi, forms of Ptah and Ptah-Sokar-Osiris. ${ }^{3}$ The ancient Egyptian tolerance for disabled appeared as well in having dwarfs and other malformed persons among the house hold of the kings and high officials. Some of those disabled persons attained high positions in the ancient Egyptian court, namely the

\footnotetext{
* Associate Professor, Minia University, Egypt.

$\uparrow$ Associate Professor, Minia University, Egypt.

1. "Disabilities," World Health Organization, accessed July 10 2015, bit.ly/1Kf0zOm.

2. M.J. Mclaughlin and L. Florian, Disability Classification in Education: Issues and Perspective (California: Crowin Press, 2008), 102-107; World Health Organization, International Classification of Functioning, Disability and Health (ICF) (Geneva: WHO, 2001), 45-47.

3. N. Ebeid, Egyptian Medicine In the Days of the Pharaohs (Cairo: General Egyptian Book Organization, 1999), 389-391.
} 
dwarfs Seneb ${ }^{4}$, Periankhw ${ }^{5}$ and Khnumhotep ${ }^{6}$, as well as Roma, the door keeper who has a shortened leg. ${ }^{7}$ Ancient Egyptians' moral instructions stressed respect for people with disabilities; as in the teachings of Amenemope;

"Beware of robbing a wretch or attacking a cripple.

Do not laugh at a blind man, nor tease a dwarf, nor cause hardship for the lame.

Don't tease a man who is in the hand of the god (i.e. ill or insane)..." 8

This was not the case in some civilizations, as it empathized the beauty and perfection of the body; parents were obliged to get rid of their deformed or disabled child who was believed to be a sign of divine anger. Their art had very few traces of showing disability. ${ }^{9}$ Though the Romans considered a deformed child is wondrous, they had a similar attitude towards the disabled and the deformed linking the quality of the soul to the perfect shape of the body. ${ }^{10}$

Ancient Egyptian art in general adopted certain rules and principles among which was the representation of the kings and tomb owners in an idealistic body in certain postures and situations. This was not the same case when dealing with minor figures, though adopting the same traditions in depicting the figures in profile with the chest and shoulders fully represented; minor figures were represented in various postures, performing different jobs. ${ }^{11}$ This probably gave the artist the chance to be more creative in trying to represent

4. Seneb was a dwarf of Egyptian origin who attained to a high position during the $5^{\text {th }}$ Dynasty (2475 BC). See N. Cherpion, "De Quand Date La Tombe Du Nani Seneb?" ["Since When Date the Tomb of Nain Seneb"], BIFAO 84 (1984): 34-54, pls.1-11.

5. Periankhw was an elite dwarf who achieved a special status as a dancer during the Old Kingdom and had a lavish burial in the royal cemetery. See Z. Hawas, "The Dancing Dwarf," The Ambassadors Online Magazine, The Forum for Culture and Civilization 7 (2004): 169, accessed June 28, 2015, bit.ly/1PjojzW.

6. Dwarf Khnumhotep was an overseer of linen during the $5^{\text {th }}$ Dynasty $(2300 \mathrm{BC})$, and had a limestone statue now in Cairo museum no.CG144. See M. E. Cody, (Ed.). Egyptian Art, Selected Writings of Bernard V. Bothmer (Oxford: Oxford University Press, 2004), 374, fig.25.2.

7. R. Sullivan, "Deformity- A Modern Western Prejudice with Ancient Origins. "Proceedings of the Royal College of Physicians Edinburgh 31, no. 3 (2001): 262; C. Kozma, "Historical Review. Dwarfs in Ancient Egypt," American Journal of Medical Genetics, no. 140 A (2006): 306-8; W.R. Dawsen, "Pygmies and Dwarfs in Ancient Egypt," JEA 24, no.2 (1938): 185.

8. F. LI. Griffith, "The Teachings of Amenophis son of Kanakht, Papyrus B.M. 10474," JEA 12, no.3/4 (Oct., 1926): 199; M. Lichtheim, Ancient Egyptian Literature, Vol. II: The New Kingdom (Berkeley: University of California Press, 1976), 149.

9. R. Sullivan, "Deformity- A Modern Western Prejudice with Ancient Origins," Proceedings of the Royal College of Physicians Edinburgh 31, no. 3 (2001): 262-3.

10. D. Smith, Introduction to Special Education: Making a Difference (Boston: Allyn \& Bacon, 2007), 4; R. Sullivan, "Deformity- A Modern Western Prejudice with Ancient Origins," Proceedings of the Royal College of Physicians Edinburgh 31, no. 3 (2001): 263-4.

11. W.S. Smith, A History of Egyptian Sculpture and Painting in the Old Kingdom. 2nd ed. (Boston: Oxford University Press, 1949), 304; N. Kanawati and A. Woods, Artists in the Old Kingdom: Techniques and Achievements (Cairo: Supreme Council of Antiquities Press, 2009), 8, 30 . 
flexible movements and real bodily features. This was probably responsible for depicting some of these figures with actual disabilities and deformities. ${ }^{12}$ The depiction of deformity expressed cultural and social acceptance of the disabled in general.

\section{Methodology}

This article aims to be an analytical and a descriptive study of the representation modes related to physical disability in Old Kingdom tomb scenes (2705-2155 BC), their different types of portrayal and interpretations. The paper would also discuss the functions of deformed individuals and specific roles in the ancient Egyptian society based on examining a group of Old Kingdom tomb scenes, in order to present a broader overview of the physical disabilities in ancient Egyptian contexts.

\section{Results and Discussion}

Types of Physical Disability in Old Kingdom Tomb Scenes

Dwarfism

Dwarfism has probably been the most commonly depicted human physical disorder. ${ }^{13}$ The ancient Egyptians documented the presence of dwarfs in almost every aspect of life. The oldest biological evidence for dwarfism in ancient Egypt dated back to the predynastic period $(4500 \mathrm{BCE}) .{ }^{14}$ The remains of dwarfs were abundant and included complete and partial skeletons. Dwarfism was also a noticeable feature in representing minor figures at work manufacturing jewelry, carrying objects, taking care of pets or even just following their masters. ${ }^{15}$

Dwarfs were commonly depicted in their work field alongside fully-grown men differentiated only by their physical deformity, which was not emphasized

12. N. Kanawati and A. Woods, Artists in the Old Kingdom: Techniques and Achievements (Cairo: Supreme Council of Antiquities Press, 2009), 36.

13.V. Dasen, "Dwarfism in Egypt and Classical Antiquity: Iconography and Medical History," Medical History, no. 32 (1988): 253-76, accessed January 25, 2016, doi: 10.1017/S0025727300048237.

14. C. Kozma, "Historical Review. Dwarfs in Ancient Egypt," American Journal of Medical Genetics, no. 140 A (2006): 303-11.

15. For example see: G. Steindroff, Das Grab des Ti, vol. II [The Grave of the Ti vol.II] (Leipzig: Hinrichs 1913), pl.15; P. Duell, The Mastaba of Mereruka, Part II (Chicago: University of Chicago Press, 1938), pl. 158; N. Kanawati and M. Abder-Raziq, Mereruka and his Family, Part 1: The Tomb of Meryteti (Oxford, England : Aris and Phillips, 2004), pl.7 (b); N. Kanawati and A. McFarlane, Deshasha: The Tomb of Inti, Shedu and Others (Sydney: Australian Centre for Egyptology, 1993), pls. 28, 33. 
o create a spectacular effect. They worked at small tables and were seated on very low stools, so that their feet could touch the ground, (Figure 1). ${ }^{16}$

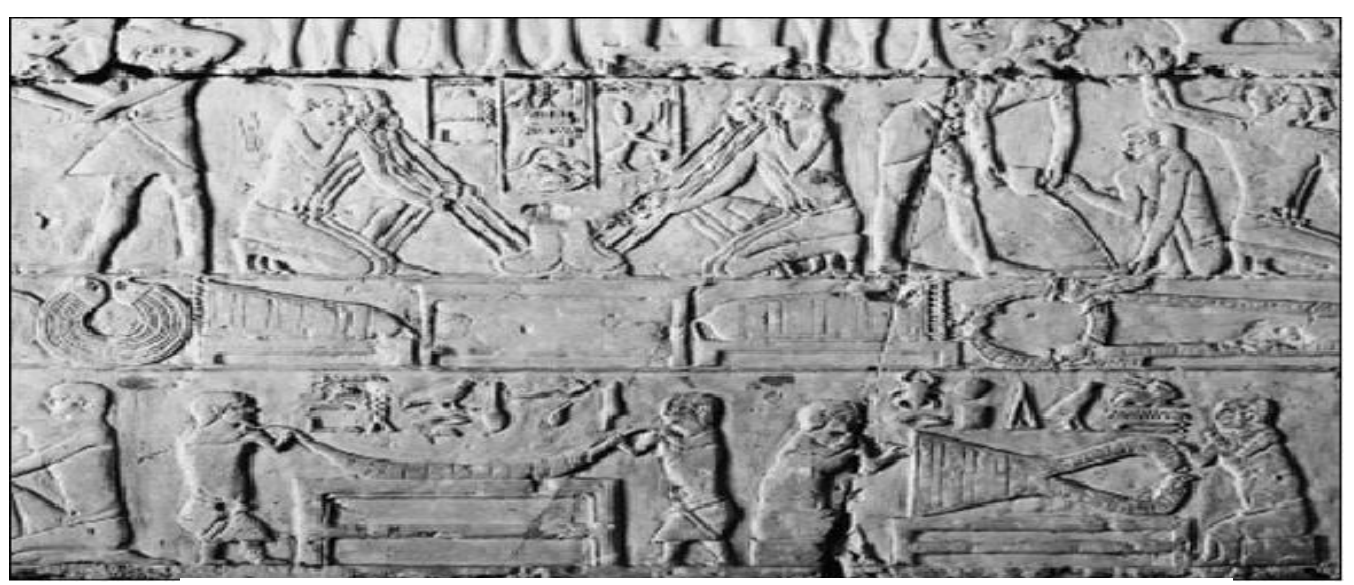

Figure 1. Dwarfs Working as Goldsmiths, Tomb of Mereruka at Saqqara

Source: N. Kanawati and A. Woods, Artists in the Old Kingdom: Techniques and Achievements (Cairo: Supreme Council of Antiquities Press, 2009), 29, Figure 21.

Several high-ranking dwarfs especially from the Old Kingdom (2705-2155 BC), achieved important status. Their costly tombs in the royal cemeteries indicated their high position in Egyptian society and their close relation to the king as well. Dwarfism comes with a number of disabilities, such as short hands, Lordosis, Kyphosis, achondroplasia and others. Fortunately, comprehensive studies were carried out on dwarfs; their typology, causes of deformities, ancient appellations, representations and status.

The hieroglyphic words for dwarfs and pygmies were $d n g$, d3ng, or $d_{3} g$, and then the word $n m w$ was known as early as the Middle Kingdom. A determinative depicting a dwarf with short limbs and a normal trunk was usually accompanied these words. ${ }^{18}$

It has been suggested that the image of dwarfs in ancient Egypt was essentially positive ${ }^{19}$, as there were many dwarf gods which were commonly involved in magical practices to protect the living and the dead. The dwarf

16. N. Kanawati and A. Woods, Artists in the Old Kingdom: Techniques and Achievements (Cairo: Supreme Council of Antiquities Press, 2009), 29, Figure 21.

17. See V. Dasen, Dwarfs in Ancient Egypt and Greece (New York: Oxford University Press, 1993); O. El- Aguizy, "Dwarfs in Ancient Egypt," (master's thesis, Cairo University, 1970); O. El- Aguizy, "Dwarfs and Pygmies in Ancient Egypt," ASAE 71 (1987): 53-60; K. R. Weeks, "The Anatomical Knowledge of the Ancient Egyptians and the Representation of the Human Figure in Egyptian Art," (PhD diss., Yale University, 1970), 158-216; P. Ghalioungui and Z. El- Dawakhly, Health and Healing in Ancient Egypt (Cairo: Egyptian Organization for Authorship and Translation, 1965), 19-20; J.F. Nunn, Medicine in Ancient Egypt (London: British Museum Press, 1996), 78-79; C. Reeves, Egyptian Medicine (Buckinghamshire: Shire Publications, 1992), 43-45; N. Ebeid, Egyptian Medicine In the Days of the Pharaohs (Cairo: General Egyptian Book Organization, 1999), 382-389;

18. V. Dasen, Dwarfs in Ancient Egypt and Greece (New York: Oxford University Press, 1993), 25-30.

19. R. Sullivan, "Deformity- A Modern Western Prejudice with Ancient Origins, "Proceedings of the Royal College of Physicians Edinburgh 31, no. 3 (2001): 262-66. 
gods, $\mathrm{Bes}^{20}$ and a miniature figure of god Ptah or the Greek Pataikos were the best known. $^{21}$

\section{Leg Deformities}

The ancient Egyptian artist believed that there is a correct manner to represent every part of the human body to express the idealism he committed to achieve. ${ }^{22}$ The leg was one of the body parts that displayed idealism with detailed lines to show the perfect muscles and bones. ${ }^{23}$ This idealism did not prevent the artist of the Old Kingdom to display the abnormalities he noticed, thus three representations from the Old Kingdom of herders with their knees turned backward.

The first is a famous scene from the $5^{\text {th }}$ Dynasty tomb of Ptahhotep at Saqqara, where a herder appears looking left while dragging a very strong fat bull with his right hand, while in the other he holds a bundle of fodder for the bull. The herder seems to be very healthy, with his body following the usual conventions of art, except for his left knee that is bent backward (Figure 2). ${ }^{24}$

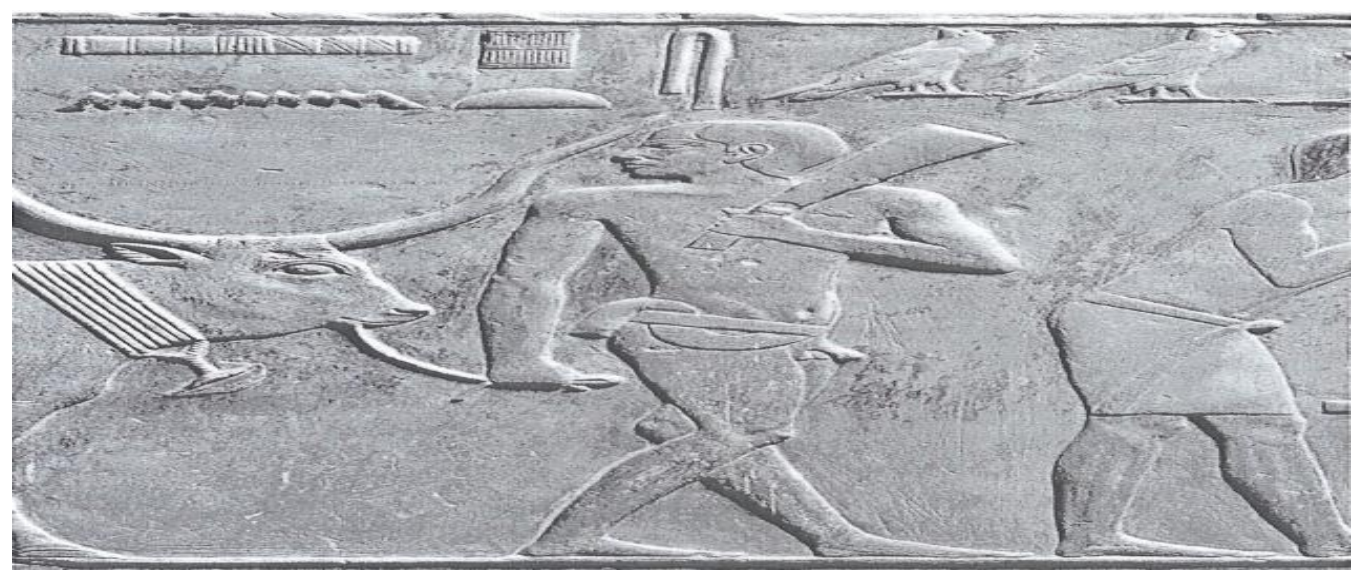

Figure 2. A Herder with a Back Knee Left Leg in the Tomb of Ptahhotep at Saqqara

Source: Y. Harpur and P.J Scremin, Chapel of Ptahhotep: Scenes details (Reading: Oxford Expedition to Egypt, 2008), 326, pls.264, 267.

20. See R. Wilkinson, The Complete Gods and Goddesses of Ancient Egypt (London: Thames \& Hudson, 2003), 49-50.

21. See M. El-Kady, "Pataikos, an Image of a Rejuvenation Divinity," Journal of Association of Arab Universities for Tourism and Hospitality 10 (part 1) (2013): 17-28.

22. K. R. Weeks, "The Anatomical Knowledge of the Ancient Egyptians and the Representation of the Human Figure in Egyptian Art," (PhD diss., Yale University, 1970), 7680.

23. Ibid., 88-91.

24. D.G. de Norman, The Mastaba of Ptah-Hotep and Akhet-Hotep at Saqqara I (London, 1900), pl.21; Y. Harpur and P.J. Scremin, Chapel of Ptahhotep: Scenes Details (Oxford: Oxford Expedition to Egypt, 2008), 326, pls.264, 267; K. R. Weeks, "The Anatomical Knowledge of the Ancient Egyptians and the Representation of the Human Figure in Egyptian Art," (PhD diss., Yale University, 1970), 95, fig.4. 
The second example comes from the $5^{\text {th }}$ Dynasty tomb of Ihy, reused by Idut at Saqqara, where another herder turned left in front of Idut (the second tomb owner). He is dragging a strong fat bull with his left hand, while in the other he holds a pot, probably with water for the bull. His right knee is turned backward (Figure 3). ${ }^{25}$ The herder of Idut is very much similar in attitude to his colleague from the tomb of Ptahhotep (Figure 2), though a number of differences can be detected in their clothes, objects they hold, their features and the leg with disability, as the one in Idut's tomb seems to be a foreigner, judging from his features and goatee. ${ }^{26}$ Some scholars assumed that it is based on the herder of Ptahhotep or copied from it, ${ }^{27}$ but there is no clear reason to assume so just because they are similar in being both half bald herders with disability in the left leg. Based on the artists' commitment to idealism, this wouldn't be a favorable icon to copy. It only can be supposed that the artist copied only an interesting case he noticed. Additionally if we compare these deformed figures with their colleagues in the same scene, we will find that the later were depicted as normal individuals with ideal proportions and perfect legs.
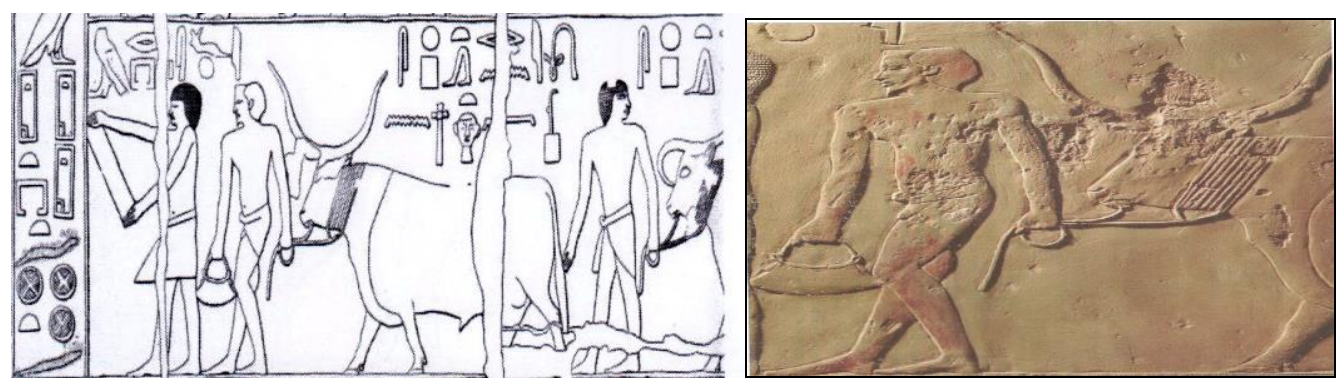

Figure 3. A Herder with a Back Knee Right Leg in the Tomb of Ihy and Idut at Saqqara

Source: N. Kanawati and M. Abder-Razi, The Unis Cemetery at Saqqara, Vol.2: The Tombs of Iynefert and Ihy (reused by Idut) (Oxford, UK: Aris and Phillips, 2003), pl.71.

25. R. Macramallah, Le Mastabad'Idout [The Mastabad'Idout] (Cairo, 1935), 26, pl. xx; N. Kanawati and M. Abder-Raziq, The Unis Cemetery at Saqqara, Vol.2: The Tombs of Iynefert and Ihy (reused by Idut) (Oxford: Aris and Phillips, 2003), pl.71; N. Kanawati, and A. Woods, Artists in the Old Kingdom: Techniques and Achievements (Cairo: Supreme Council of Antiquities Press, 2009), fig.31.

26. Two examples of Beja African herders suffering from the back knee are to be found in two Middle Kingdom tombs at Meir. See A.M. Blackman, The Rock Tombs of Meir. Part I: The Tomb Chapel of Ukh-Hotp's son Senbi (London: The Egypt Exploration Society, 1914), 32-33,pls.ix, xxv(3) and xxvi (1); A.M Blackman, The Rock Tombs of Meir. Part II: The Tomb Chapel of Senbi's son Ukh-Hotp (B, No.2) (London: The Egypt Exploration Society,1915), pl.iii; E. Chassinat, "Á propos d'un bas-relief du tombeau de Senbi á Meir" ["About a basrelief of the tomb of Senbi á Meir"] BIFAO 10 (1915): 169-170, fig.1; J. Cladet, "Notes sur Quelques Figures Égyptienne" ["Notes on some Egyptian Figures"] BIFAO 1 (1901): 21, fig.1; E. Chassinat, " Notes Prises a Mair," ["Notes Taken at Main"], RT 22 (1911): 73-5.

27. K. R. Weeks, "The Anatomical Knowledge of the Ancient Egyptians and the Representation of the Human Figure in Egyptian Art," (PhD diss., Yale University, 1970), 9596. 
The third depiction is from the tomb of Iymery at Giza. Though slightly damaged one can detect a herdsman thinner than his fellow herdsmen in the scene. He is holding a stick and seems to be driving a fat ox. Similar in manner of the herder in the tomb of Ptahhotep, his left knee is bent backward as well (Figure 4) ${ }^{28}$ The short stick in the herder's hand might have been used either to help in controlling the oxen or as a walking aid due to his medical condition. ${ }^{29}$ Though the above cited examples did not have such a device, which is surprising, as handling oxen and moving with a leg disability certainly needs assistance. Besides he was not depicted holding the staff in the usual way, he was gripping it between his chest and upper arm, leaving his both hands free to do his work. A position which was very characteristic and rarely represented. ${ }^{30}$

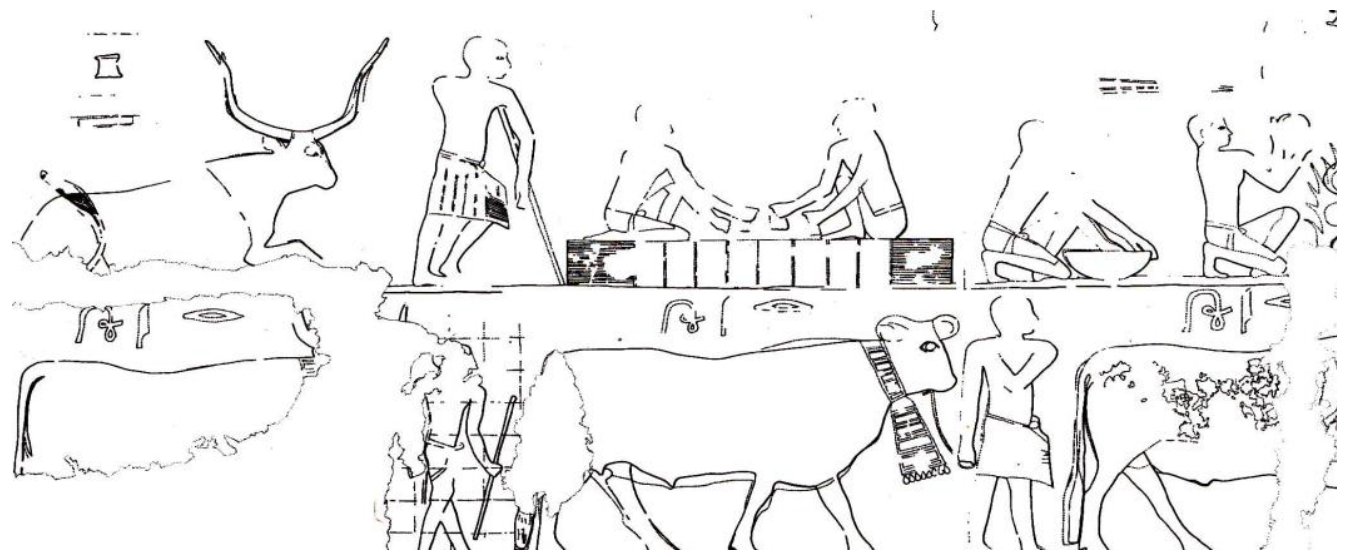

Figure 4. A Herdsman with a Deformity in His Left Leg and He Was Relied on a Stick in the Tomb of Iymery at Giza

Source: K.R Weeks, Mastabas of Cemetery G 6000 (Boston: Museum of Fine Arts, 1994), 42, fig.34 (second register).

Scholars agreed that the disease causing the back knee is what is medically known as "genu recurvatum". It is one of the diseases that cause the leg to be concave, and that the knee joint bends backward. This disease is more frequent in females than in males and causes difficulties in moving. ${ }^{31}$ The back knee may occur as a result of bad bone structure, fractures in the bones or the joints,

28. K.R Weeks, Mastabas of Cemetery G 6000 (Boston: Museum of Fine Arts, 1994), 42, fig.34(second register).

29. W.Y. Loeb and J.F. Nunn, "Staffs as Walking Aids in Ancient Egypt and Palestine," Journal of the Royal Society of Medicine, no. 90(1997): 453.

30. It was also depicted on Khety's tomb at Beni Hassan in the 11th Dynasty (Middle Kingdom), N. Kanawati and A. Woods, Beni Hassan Art and Daily Life in an Egyptian Province (Cairo: Supreme Council of Antiquities Press, 2010), 168.

31. D. M. Hart and M. F. Macnicol, "The Knee" in Children's Orthopedics and Fractures, ed. M. Benson, J. Fixsen, M. Macnico (London: Churchill Livingstone, 2010), 495-515; L. Stedman, Medical Dictionary 24th ed. (London: William \& Wilkins, 1982), 582; H. Kamal, Dictionary of Pharaonic Medicine (Cairo: National Publication House, 1967), 258. 
weakness of the knee muscles due to poliomyelitis, though it is scarce in ancient Egypt. ${ }^{32}$

The Ebres Papyrus perhaps supplied an appellation for this disease, as a statement refers to a prescription to treat it; "kt nt rd-hm.s"s33, which could be translated as; "another for knee which swings backward". ${ }^{34}$

The word $h m$ may also be translated as a "knee disease" ${ }^{35}$ not particularly the back knee.

Weeks suggested that this condition is one of the symptoms of "genu valgum". ${ }^{36}$ In this case the leg disability here is showing a late stage of rickets, a very well recorded disease in ancient Egypt resulting from deficiency in vitamin D and causes leg bending. ${ }^{37}$

A scene from the tomb of Mersyankh III representing a herder driving a cow may be considered as having a leg deformity. His right leg looks so thin as if it is lame or perhaps is infected with polio. ${ }^{38}$ Comparing this herder with his fellows in the same scene, he is generally thin. This is a common feature of poliomyelitis. Another example was dated back to the $6^{\text {th }}$ Dynasty in the tomb of Nikauisesi at Saqqara. The tomb owner Nikauisesi himself was depicted leaning on his staff while his forward left leg was bent may be as a result of poliomyelitis, (Figure 5). ${ }^{39}$

32. K.R. Weeks, "The Anatomical Knowledge of the Ancient Egyptians and the Representation of the Human Figure in Egyptian Art" (PhD diss., Yale University, 1970), 9697.

33. W. Wreszinski, Die Medizin der alten Ägypter III. Der Papyrus Ebers. Umschrift, Übersetzung und Kommentar [The medicine of the ancient Egyptians III. The Papyrus Ebers. Transliteration, translation and commentary] (Leipzig, 1913), 152, no.604, § 76, 22.

34. B. Ebbell, The Papyrus Ebres: the Greatest Egyptian Medical Document (Copenhagen: Levin \& Munksgaard, 1937), 91.

35. A. Erman and H. Grapow, Wörterbuch der Aegyptischen Sprache (Wb III) [Dictionary of Egyptian Language (vol III)] (Berlin: Akademie-Verlag, 1926-1961), 79, 22.

36. K. R. Weeks, "The Anatomical Knowledge of the Ancient Egyptians and the Representation of the Human Figure in Egyptian Art" (PhD diss., Yale University, 1970), 97, figs.10-13.

37. M. El Shafey, "Congenital Anomalies of Individuals in Ancient Egyptian Art till the End of the New Kingdom" (master's thesis, Tanta University, 1998), 18-26; W. J. Darby, P. Ghalioungui, L. Grivetti, Food: The Gift of Osiris Vol. 1 (London, UK: Academic Press, 1977), 79, fig.2.12; N. Ebeid, Egyptian Medicine In the Days of the Pharaohs (Cairo: General Egyptian Book Organization, 1999), 396-397; H. Kamal, Dictionary of Pharaonic Medicine (Cairo: National Publication House, 1967), 187; L. Stedman, Medical Dictionary 24th ed. (London: William \& Wilkins, 1982), 1238.

38. D. Dunham and W. K. Simpson, The Mastaba of Queen Mersyankh III G.7530-7540 (Boston: Museum of Fine Arts, 1974), pl. IV, Fig.4; Kanawati and Woods, Old Kingdom, 70, Photo 104.

39. N. Kanawati and M. Abder-Raziq, The Teti Cemetery at Saqqara: Vol.VI. The Tomb of Nikauisesi (Warminster, England: Aris and Phillips, 2000). 


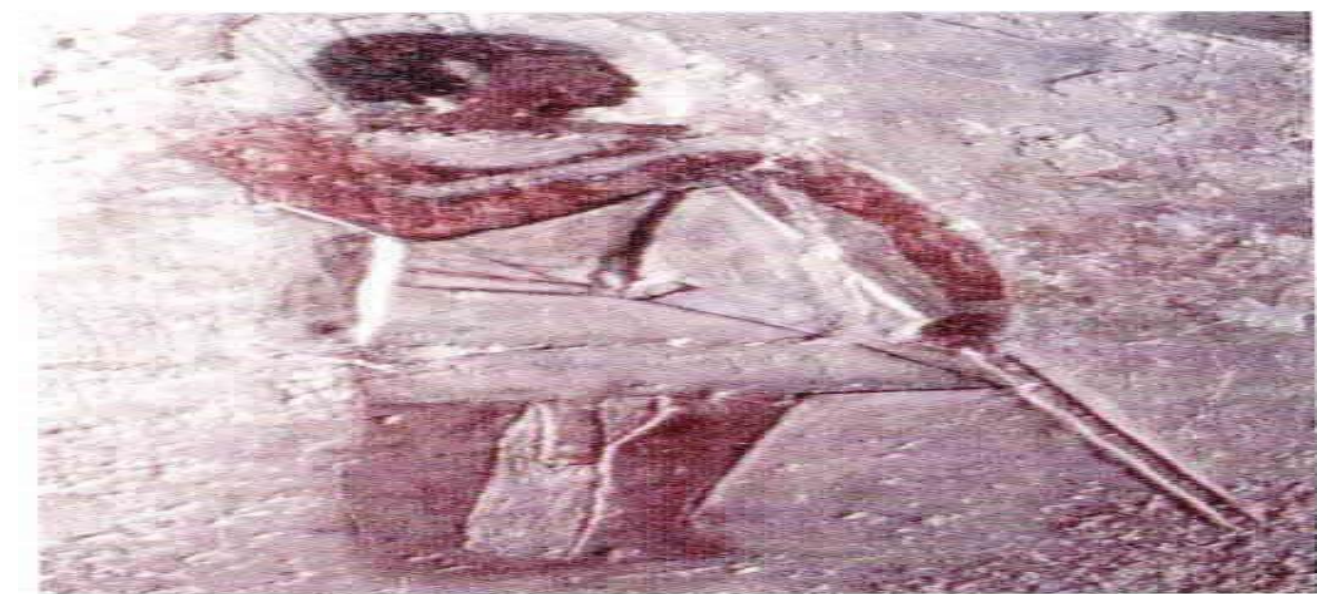

Figure 5. Nikauisesi, a Tomb Owner with A Deformity in His Left Leg and He Was Relied on a Stick in His Tomb at Saqqara

Source: N. Kanawati and R. Abder, The Teti Cemetery at Saqqara: Vol.VI. The Tomb of Nikauisesi (Warminster, England: Aris and Phillips, 2000).

Polio on the other hand might have been a common disease in ancient Egypt. Individuals with poliomyelitis were depicted on the tomb wall scenes and stela ${ }^{40}$ as early as the Old Kingdom and afterwards. The disease was also discovered on examination of Egyptian mummies. It is caused by a virus that infects cells of the central nervous system. It results in cell destruction and causes paralysis of one leg or perhaps both. ${ }^{41}$

\section{Back Deformities}

The spine is made up of small vertebrae piled up with discs, one on top of another. A normal spine has gentle curves to it and should run straight down the middle of the back. The curves help the spine absorb stress caused by the body movement. Misalignment of the natural curvature occurs due to some diseases as with Kyphosis and Scoliosis. ${ }^{42}$

Kyphosis

The word is derived from the Greek term kyohos, a hump. ${ }^{43}$ It is a deformity that causes an over-curvature of the upper back, making a hump at

40. See the Stela of Roma, the door-keeper of the 18th or the 19th Dynasty (1300 BC) exhibited in Carlsberg museum, Copenhagen, who was depicted with a deformed leg due to poliomyelitis. See W.Y. Loeb and J. F. Nunn, "Staffs as Walking Aids in Ancient Egypt and Palestine," Journal of the Royal Society of Medicine, no. 90 (1997): 450-54, figure 7.

41. N. Ebeid, Egyptian Medicine In the Days of the Pharaohs (Cairo: General Egyptian Book Organization, 1999), 401-3, figs.20.21- 20.23.

42. L. Stedman, Medical Dictionary 24th ed. (London: William \& Wilkins, 1982), 1552; M. El Shafey, "Congenital Anomalies of Individuals in Ancient Egyptian Art till the End of the New Kingdom," (master's thesis, Tanta University, 1998), 37. Lordosis lies among back deformities but it is strongly attached to dwarfs and obesity sometimes, thus it is not in the scope of the present article.

43. L. Stedman, Medical Dictionary 24th ed. (London: William \& Wilkins, 1982), 751. 
the back which causes a deformity in the bones of the rib cage where they become very close to each other. This condition could be accompanied by a side curve of the spine known as Kypho-Scoliosis. ${ }^{44}$

Kyphosis or a Hunched back may occur as a result of structural deformity during pregnancy causing a congenital humping, where the whole body is normal but with a round hump at the back. ${ }^{45}$ Kyphosis may also happen due to Osteomalacia, poor stature and weakening of the muscles and ligaments in the back during adolescence. The hump in this case is round. ${ }^{46}$

Kyphosis may come as a result of certain professions, as working as scribes, jewelry makers. Setting for long hours affects the longitudinal muscles around the spine. Carrying heavy loads as well may affect the shoulders and the back. Old age is may be one of the causes of Kyphosis as well But in this case the whole back becomes round, not only its upper part. ${ }^{47}$

Tuberculosis of the spine is one of the major causes of Kyphosis. It is known as Pott's disease. It causes an angular hump at the back. It is caused by bacteria through human contact with infected livestock. ${ }^{48}$ Pott's disease hits the bone marrow, and goes through the spine, weakening it under the pressure of the body weight, thus causing a hunched back. It also causes shortening of the trunk and restricting growth. It is more common in males and in young people than adults. ${ }^{49}$ It was relatively common in ancient Egypt. It is very well recorded in mummies, statues and scenes since the Predynastic period. ${ }^{50}$

44. Ibid., 752; F. Jonckheere, "Le Bossu Des Musées Royauxd'Art et d'Histoire de Bruxelles" ["The Hunchback of Royal Museum of Art and History of Brussels"] CdE 23 (1948): 32-3.

45. J. Filer, Diseases (London: British Museum Press, 1995), 15; A. Hamzaoglu, et al., "Simultaneous Surgical Treatment in Conenital Scoliosis and/ or Kyphosis Associated with Intraspinal Abnormalities," SPINE 32, no. 25 (2007): 2880.

46.E. H. Ackerknecht, "Paleopathology," in Anthropology Today, ed. A.L. Kroeber (Chicago: Univ. of Chicago Press, 1953).

47. M. El Shafey, "Congenital Anomalies of Individuals in Ancient Egyptian Art till the End of the New Kingdom," (master's thesis, Tanta University, 1998), 38-9.

48. C. Reeves, Egyptian Medicine (Buckinghamshire: Shire Publications, 1992), 33.

49. H.E Sigerist, A History of Medicine Vol. I, Primitive and Archaic Medicine, (New York: Oxford University Press, 1951), 53; N. Ebeid, Egyptian Medicine in the Days of the Pharaohs (Cairo: General Egyptian Book Organization, 1999), 397, fig.20, 18; F. Jonckheere, "Le Bossu Des Musées Royauxd'Art et d'Histoire de Bruxelles" ["The Hunchback Of Royal Museum Of Art and History of Brussels"] CdE 23 (1948): 33-4.

50. P. Gilbert, "La Date de la Figurine de Bossu" ["The date of the figurine of Bossu"], $C d E$, no. 23 (1948): 35; M.A. Ruffer, Studies in the Paleopathology of Egypt (Chicago: The University of Chicago Press, 1921), 3-10, 42, pl.1; H.E Sigerist, A History of Medicine Vol. I, Primitive and Archaic Medicine (New York: Oxford University Press, 1951), 53-4, figs.9-10; D. Morse, D. R. Brothwell, and P.J. Ucko, "Tuberculosis in Ancient Egypt," American Revue of Respiratory Disease 90 (1964): 524-41; H. Kamal, Dictionary of Pharaonic Medicine (Cairo: National Publication House, 1967),484-5; C. Reeves, Egyptian Medicine (Buckinghamshire: Shire Publications,1992), 33-34, figs. 21, 22;. F. Jonckheere, "Le Bossu Des Musées Royauxd'Art et d'Histoire de Bruxelles" ["The Hunchback of Royal Museum of Art and History of Brussels"] CdE 23 (1948): 24-29; J. Filer, Diseases (London: British Museum Press, 1995), 33. 
A hunched back person was known as $i w$ since the Middle Kingdom (2134-1781 BC). ${ }^{51}$ The word was even written with a determinative of a man with a hump. ${ }^{52}$ spine:

Again the Ebres Papyrus probably indirectly refers to tuberculosis of the

"ỉr di.k s ḥr mn r ỉb.f gm.k st ḥr psd.f mi ${ }^{3 t}$ pwt n h̆ry- dmt dd hr.kr.s whdw pw tḥy har psd.f"

The text could be translated as; "If you examine a man for illness in his heart and you find it on his back like the trouble (suffering) of one who has been stung. Then you shall say to him: it is purulence which has violated his back". $^{54}$

It has been suggested by Ebbell that the mentioned disease is tubercular spondylitis, as it involves purulence in the back. ${ }^{55}$ Thus the sentence "the trouble (suffering) of one who has been stung" could be an indirect metaphor of the hump caused by Tuberculosis.

Artistically, it was a dilemma for the artist to show a back hump while representing the person in profile. This is probably why the hump usually appears near or behind the shoulders, especially if the person is not in action. When doing activities the artist had the chance to show the hump, but the arms looks too close and the chest space is too tight. ${ }^{56}$

The $5^{\text {th }}$ Dynasty tomb of Seshemnefer I, G 4940 offers a very interesting example of a woman with an angular hunched back. Her arms are peculiarly modeled probably due to the artist's attempt to stress the hump while placing the shoulder in a frontal view (Figure 6). ${ }^{57}$

51. A. Erman and H. Grapow, Wörterbuch der Aegyptischen Sprache (Wb III) [Dictionary of Egyptian Language (Vol III)] (Berlin: Akademie-Verlag, 1926-1961), 43, 11; K. R. Weeks, "The Anatomical Knowledge of the Ancient Egyptians and the Representation of the Human Figure in Egyptian Art," (PhD diss., Yale University, 1970), 172, 216, fig.13.

52. R. O. Faulkner, A Concise Dictionary of Middle Egyptian (Oxford: Griffith Institute, 1962), 11.

53. W. Wreszinski, Der Papyrus Ebres: Umschrift, Übersetzung Und Kommentar [The Ebers Papyrus: Transcription, Translation and Comment] (Leipzig: J.C. Hinrichs, 1913), 57, no.200, § 40, 6-7.

54. B. Ebbell, The Papyrus Ebres: The Greatest Egyptian Medical Document (Copenhagen: Levin \& Munksgaard, 1937), 51.

55. Ibid., 51, n.2.

56. M. El Shafey, "Congenital Anomalies of Individuals in Ancient Egyptian Art till the End of the New Kingdom" (master's thesis, Tanta University, 1998), 60-1.

57. W.S. Smith, A History of Egyptian Sculpture and Painting in the Old Kingdom. 2nd ed. (Boston: Oxford University Press, 1949), 313-14, fig. 178 (right); K. R. Weeks, "The Anatomical Knowledge of the Ancient Egyptians and the Representation of the Human Figure in Egyptian Art," (PhD diss., Yale University, 1970), 177; M. Alonso, "La Stele di anx- wD.s della Glittoteca Ny Carlsberg Di Copenhagen" [The Stele of nx-WDC of the Ny Carlsberg Glyptotek in Copenhagen, Prospective Study], BSÉG 21 (1997): 53, fig.12; Kanawati, N. "Tombs at Giza, Kaiemankh (G 4561) and Seshemnefer I (G 4940)", Vol I, Australian Centre for Egyptology Report 16 (Warminster: Aris and Phillips, 2001), pl.47.Another hunched back woman from the 5th Dynasty is represented by a wooden statue in the Egyptian Museum. See 


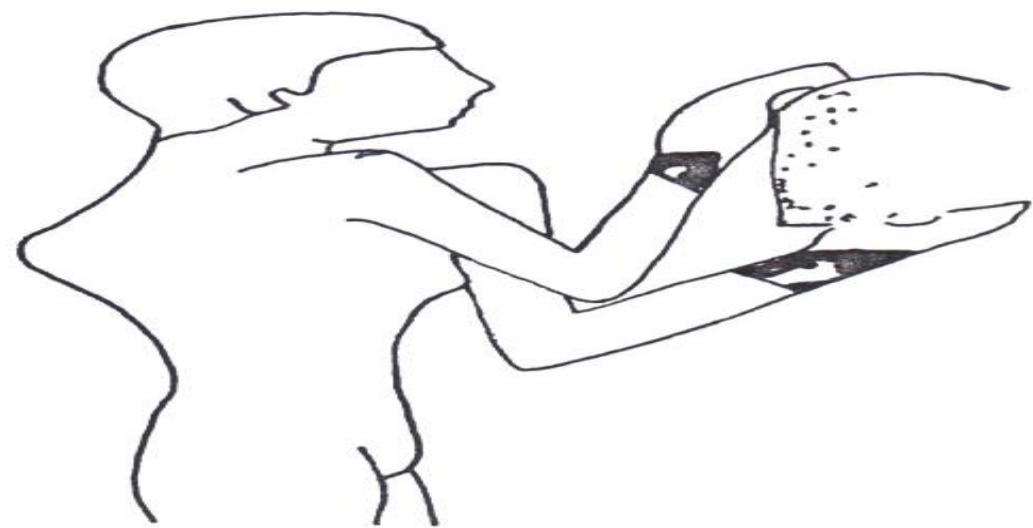

Figure 6. A Female Offering Bearer Was Depicted With An Angular Hunched Back, in the Tomb of Seshemnefer I at Giza

Source: W.S. Smith, A History of Egyptian Sculpture and Painting in the Old Kingdom, 2nd ed. (Boston: Oxford University Press, 1949), 313-14, fig.178 (right).

A hunched back dog holder appears in the famous Saqqara tomb of Ti. A clear Kypho-Scoliosis syndrome is shown (Figure 7$){ }^{58}$ The right shoulder looks higher than the left as he suffers from a side curve as a result of his illness.

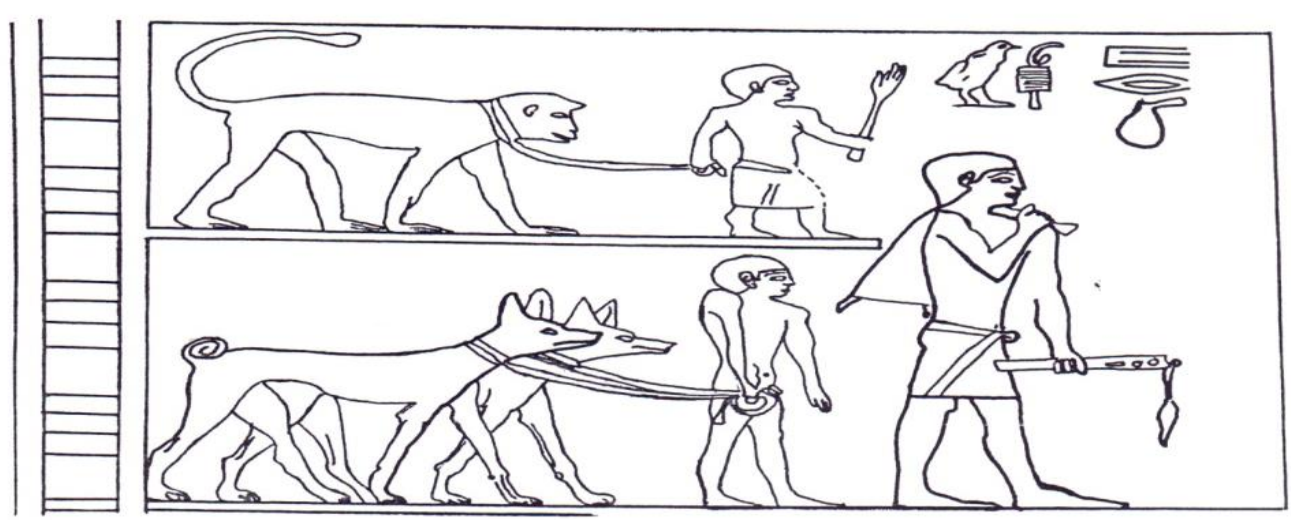

Figure 7. A Hunched Back Dog Holder, In the Tomb of Ti at Saqqara Source: H. Wild, Le Tombeau de Ti, vol. II [The Tomb of Ti] (Cairo, 1953), pl.26.

A hunched back squatting herder is seen in the tomb of Ptahotep. His round hump is apparent just behind his left shoulder as he is depicted in profile. His elongated head may also represent a deformity. Ironically the bull he is feeding has deformed horns as well (Figure 8). ${ }^{59}$

R. Engelbach, "Some Remarks on Ka Statues of Abnormal Men in the Old Kingdom," ASAE 38 (1938): 285, fig.2; J. Filer, Diseases (London: British Museum Press, 1995), 79, fig.43.

58. H. Wild, Le Tombeau de Ti, vol. II [The Tomb of Ti] (Cairo, 1953), pl.26; F. Jonckheere, "Le Bossu Des Musées Royauxd'Art et d'Histoire de Bruxelles" ["The Hunchback of Royal Museum of Art and History of Brussels"] CdE 23 (1948): 28.

59. Y. Harpur and P.J. Scremin, Chapel of Ptahhotep: Scenes Details (Oxford: Oxford Expedition to Egypt, 2008), 323, pls. 246-247. For other scenes of deformed horns see: N. Kanawati and A. Woods, Artists in the Old Kingdom: Techniques and Achievements (Cairo: Supreme Council of Antiquities Press, 2009), 78, n.20. 


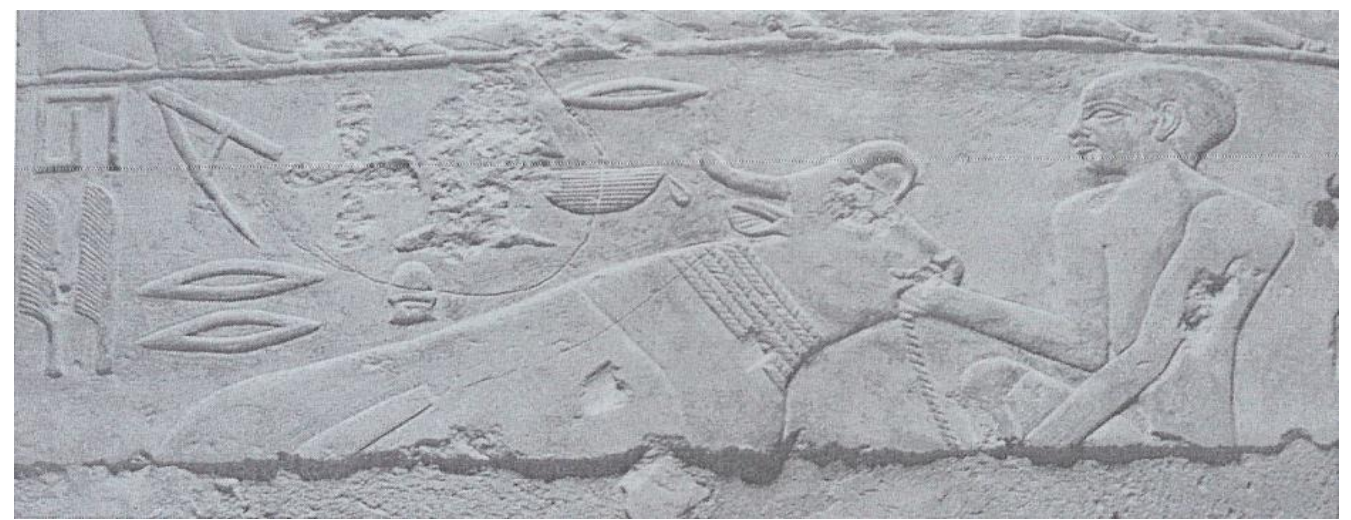

Figure 8. A Hunched Back Squatting Herder with Round Hump, Was Feeding a Bull in Ptahhotep Tomb at Saqqara

Source: Y. Harpur and P.J Scremin, Chapel of Ptahhotep: Scenes details (Reading: Oxford Expedition to Egypt, 2008), 326, pls.264, 267.

A very interesting example is represented in the Saqqara tomb of Nykahem and Sekhemenhathor, where a dog holder is represented among other bearers with a round hump on his back and a deformed chest (Figure 9). ${ }^{60}$ It seems that the artist failed to express both the back and the chest deformities and show normal arms at the same time. It looks confusing; which arm is left and which is right. In one of his hands he holds a curved staff, a form of the awt-staff. This staff perhaps belongs to the tomb owner as a second staff is being held as well by a second man in a procession of bearers holding other objects including sandals. ${ }^{61}$ This staff can also belong to the deformed dog holders and probably was used as a walking aid as the case in some deformed individuals, such as Roma. ${ }^{62}$

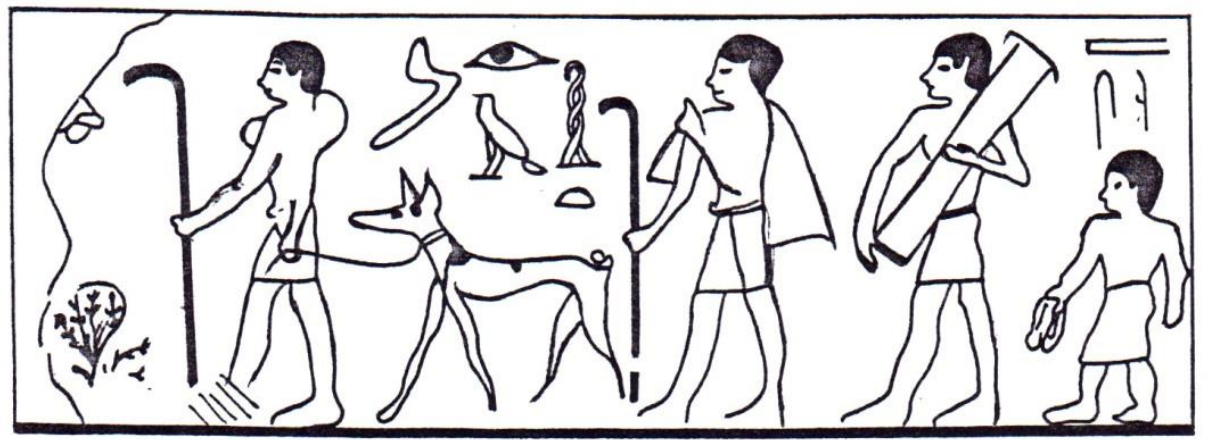

Figure 9. A Dog Holder with a Round Hump on His Back and A Deformed Chest, Tomb of Nykahem and Sekhemen-Hathor at Saqqara

Source: J.E. Quibell, Excavations at Saqqara: vol. II (Cairo: IFAO, 1909), 115, pl. 62.

60. J.E. Quibell, Excavations at Saqqara: vol. II (Cairo: IFAO, 1909), 115, pl. 62.

61. H.G. Fischer, "Notes on Sticks and Staves in Ancient Egypt," MMAJ 13 (1978): 7, fig.2c.

62. W.Y. Loeb and J. F. Nunn, "Staffs as Walking Aids in Ancient Egypt and Palestine," Journal of the Royal Society of Medicine, no.90 (1997): 453. 
On the contrary of this example, in the case of a round humped back and deformed chest man from the tomb of Nikauisesi; the artist succeeded in expressing both deformities and managed to differentiate between both arms, though the hump seems to be an extension of the left arm (Figure 10). The man is titled s $\underline{d}^{3} w t y-I t y$, "the seal bearer, Ityi" ${ }^{63}$. He is represented under the chair of the tomb owner, and it seems that his deformity is not in the way of his work. His right hand supports a box with the help of his head, probably instead of his shoulder, while in his left hand he holds an elegant dog. His upper part is huge. The chest ribs are apparent while his lower part is smaller, which is normal in such physical deformities.

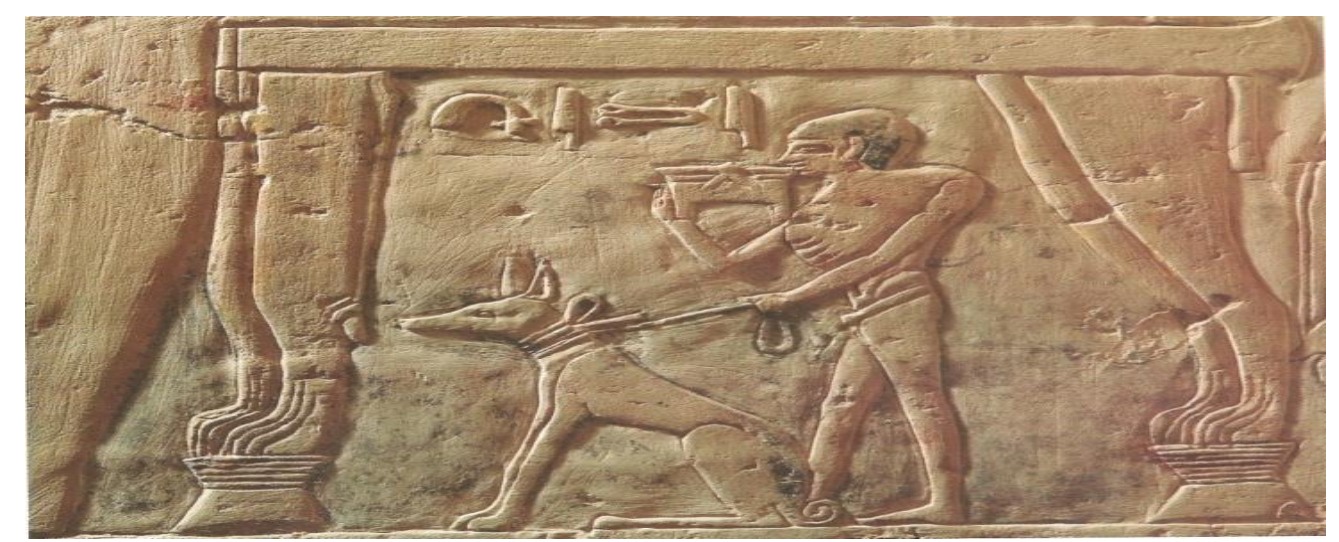

Figure 10. A Dog Holder with a Round Humped Back and Deformed Chest, In the Tomb of Nikauisesi at Saqqara

Source: N. Kanawati and A. Woods, Artists in the Old Kingdom: Techniques and Achievements (Cairo: Supreme Council of Antiquities Press, 2009), Photo 103.

On one of the walls of the Meidum tomb G.2184, a pointed hunched back man is represented while skinning an animal hanged from a tree (Figure 11). ${ }^{64}$ It is noticeable that his arms are elongated with no apparent shoulders. Both arms seem to stem from the same point. Could the hump on his back be a peculiar representation of the shoulder? Representing an action of work that the artist failed to represent!

This depiction may belong to a serious of representations that are somehow confusing. They could represent either real hunched back men or can be just an error of an artist failed to express certain activities.

63. N. Kanawati and M. Abder-Raziq, The Teti Cemetery at Saqqara: Vol.VI. The Tomb of Nikauisesi (Warminster, England: Aris and Phillips, 2000), 36, pl.48; N. Kanawati and A. Woods, Artists in the Old Kingdom: Techniques and Achievements (Cairo: Supreme Council of Antiquities Press, 2009), Photo 103.

64. W.S. Smith, A History of Egyptian Sculpture and Painting in the Old Kingdom 2nd ed. (Boston: Oxford University Press, 1949), 364, fig.238. 


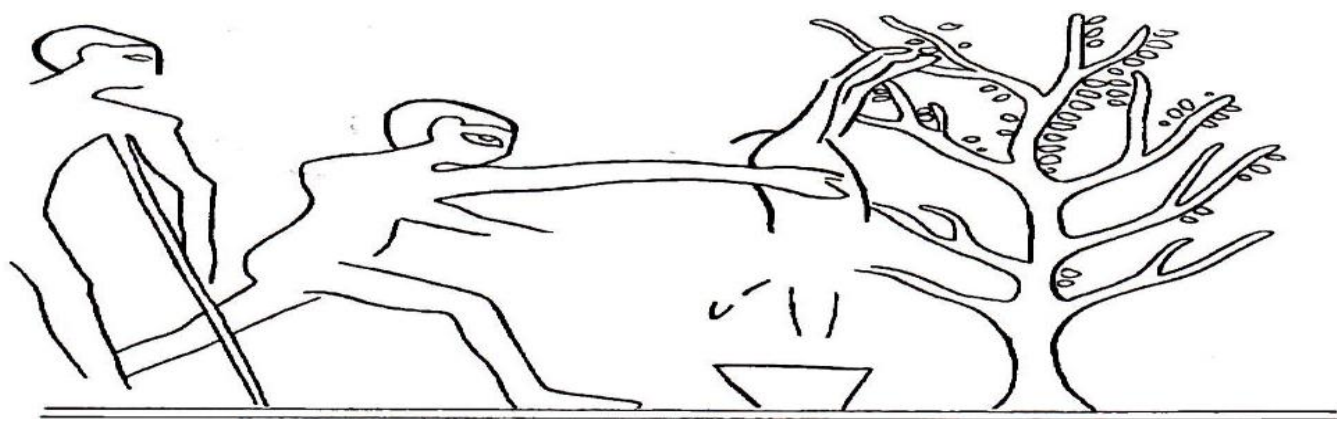

Figure 11. A Pointed Hunched Back Man Who Was Skinning an Animal Hanged From a Tree, In the Tomb of Akhmerutnisu at Giza

Source: W.S. Smith, A History of Egyptian Sculpture and Painting in the Old Kingdom, 2nd ed. (Boston: Oxford University Press, 1949), 364, fig.238.

Among these depictions comes a relief of a man cutting grain from the $4^{\text {th }}$ Dynasty tomb of Khafraankh at Giza (Figure 12). ${ }^{65}$ He has a hump on his back and the cutting tool seems as an extension of the arm; definitely an artist's error. This could support the idea that the hump may be a bad representation of the shoulder movement while cutting, especially that the proportions of the body look normal.

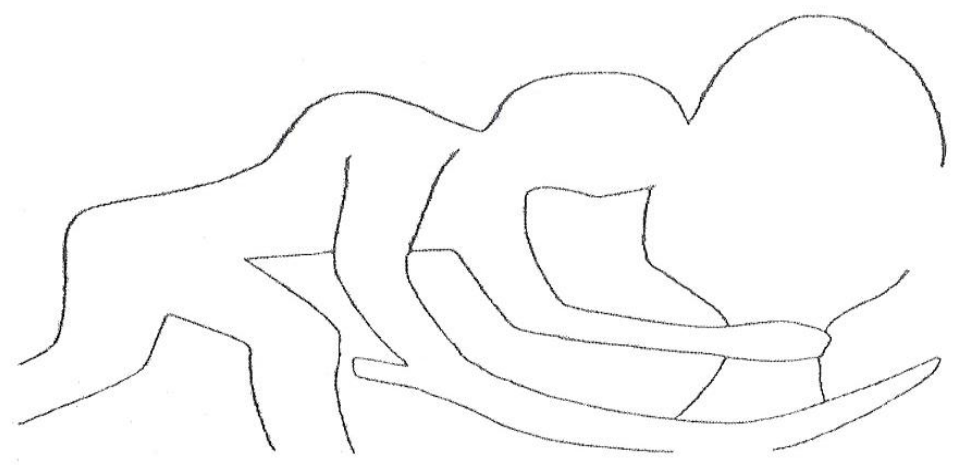

Figure 12. A Hunched Back Man Was Cutting Grain, in the Tomb of Khafraankh at Giza

Source: W.S. Smith, A History of Egyptian Sculpture and Painting in the Old Kingdom, 2nd ed. (Boston: Oxford University Press, 1949), 313, fig. 175.

Another example from the tomb of Khunra at Giza which dated back to the $4^{\text {th }}$ Dynasty, involving a boat builder with a small hump on his shoulder. It seems that the artist here failed to show the movement of the worker's shoulder while tightening the truss of the hull. ${ }^{66}$

65. W.S. Smith, A History of Egyptian Sculpture and Painting in the Old Kingdom 2nd ed. (Boston: Oxford University Press, 1949), 313, fig. 175 (first figure); K. R. Weeks, "The Anatomical Knowledge of the Ancient Egyptians and the Representation of the Human Figure in Egyptian Art," (PhD diss., Yale University, 1970), 148.

66. W.S. Smith, A History of Egyptian Sculpture and Painting in the Old Kingdom 2nd ed. (Boston: Oxford University Press, 1949), 313, fig. 175 (third figure). It is noticeable that in 
A striking model of a man called Ankhwedjes who was modeled with his left arm attached backward with a small hump under the upper part of the arm (Figure 13). ${ }^{67}$ Many scholars agreed that this person suffered from Kyphosis as a result of the Pott's disease.$^{68}$ But the hump does not look that clear to decide if Ankhwedjes had a real hump or that it was only an artist's error. Some scenes of tomb owners in profile might support this like in the scene of Kaaper, where his right arm seems as if a separate part attached to the body. The point where the left shoulder is supposed to be connected to the body is very long. ${ }^{69}$

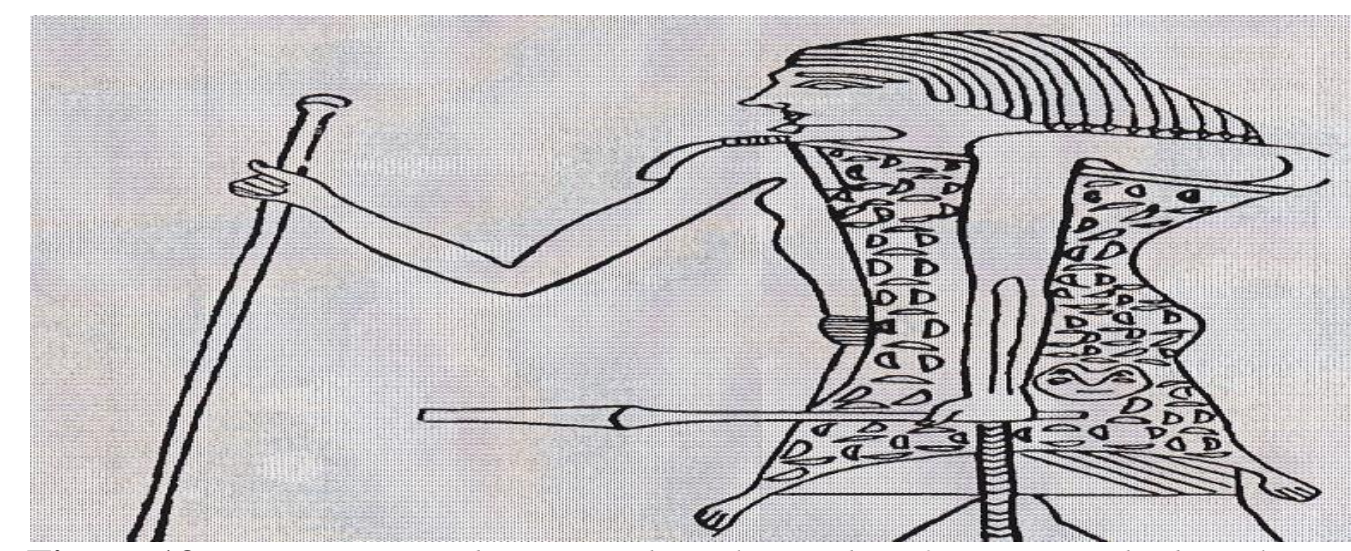

Figure 13. A Man Dressed in a Panther Skin with Left Arm Attached Backward with a Small Hump under the Upper Part of the Arm, in the Tomb of Ankhwedjes

Source: H. Madsen, "EinKünstlerisches Experiment imAltenReiche" ["An artistic experiment in Old Kingdom"], ZÄS 42 (1905): 65-66, Abb.1

In spite of these possible errors, the ancient Egyptian artist succeeded in differentiating between kyphosis resulting in severe hunched back due to certain diseases, and the whole round back caused by long hours in certain professions.

another more detailed publication of the same scene, the hump does not make an appearance. See E. M. Rogers, "An Analysis of Tomb Relief Depicting Boat Construction from the Old Kingdom Period in Egypt" (master's thesis Texas University, 1996), 78, fig.43.

67. H. Madsen, "Ein Künstlerisches Experiment im AltenReiche" ["An artistic experiment in Old Kingdom"], Z̈̈S 42 (1905): 65-66, Abb.1; W.S. Smith, A History of Egyptian Sculpture and Painting in the Old Kingdom. 2nd ed. (Boston: Oxford University Press, 1949), 304, fig.157; O. Koefoed-Petersen, Catalogue des Bas- Reliefs et Peintures Egyptiens [Catalog of Bas Reliefs and Egyptian Paintings] (Copenhagen: Glyptotheque ny Carlsberg , 1957), 20-21, pl.XVIII.

68. H. Solmann, "La Maladie d'ankh-utus" [" The Disease of ankh-utus"], BMSA 17 (1927): 61; M. Mogensen, La Glyptotheque Ny Carlsberg, La Collection Egyptienne [The Ny Carlsberg Glyptotek, The Egyptian Collection]. Copenhagen, 1930, 90, pl.CXV; M. Alonso, "La Stele di anx- wD.s della Glittoteca Ny Carlsberg Di Copenhagen" [The Stele of nx-WDC of the Ny Carlsberg Glyptotek in Copenhagen, Prospective Study], BSÉG 21 (1997): 51-4, fig.1. For more examples of possible humps and artists errors see K. R. Weeks, "The Anatomical Knowledge of the Ancient Egyptians and the Representation of the Human Figure in Egyptian Art," (PhD diss., Yale University, 1970), 148.

69. N. Kanawati and A. Woods, Artists in the Old Kingdom: Techniques and Achievements (Cairo: Supreme Council of Antiquities Press, 2009), Photo 71. 
Two scenes of two professions from the tomb of Ptahhotep are clear examples of this. The first represents a squatting old aged fish gutter, with a bent back making a round hump (Figure 14). ${ }^{70}$ The artist was successful in detailing the posture of the fish gutter, as he supports his chest on his knee to do the required work. Not all fish gutters were represented in this manner. ${ }^{71}$ Probably he took this shape from spending many years doing this job. $^{72}$

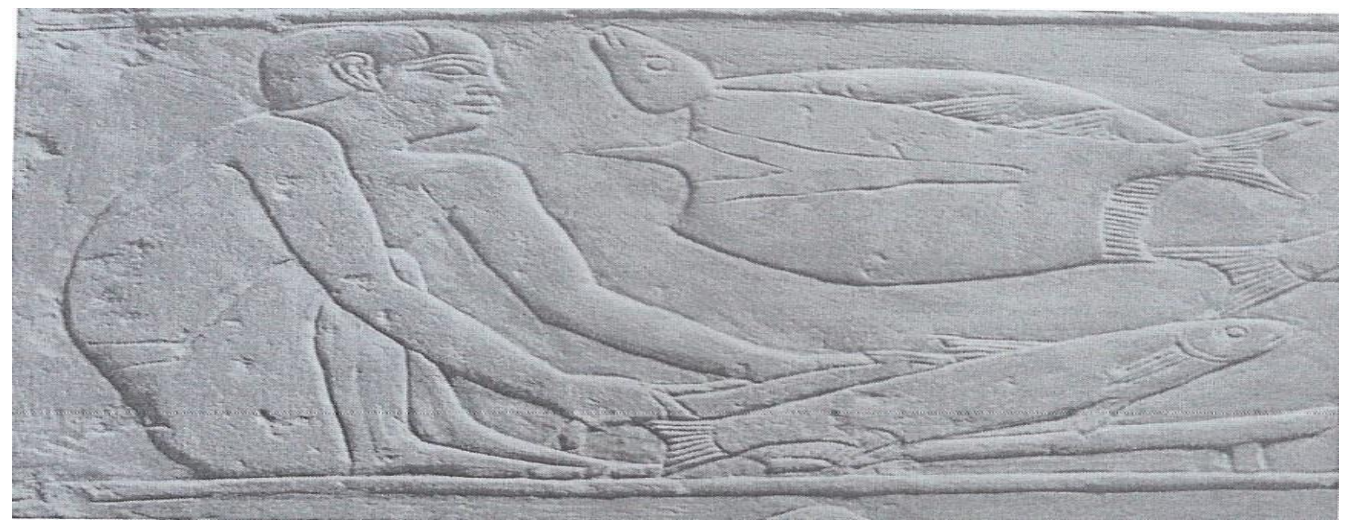

Figure 14. An Old Aged Fish Gutter with a Round Hunched Back, in the Tomb of Ptahhotep at Saqqara

Source: Y. Harpur and P.J Scremin, Chapel of Ptahhotep: Scenes Details (Reading: Oxford Expedition to Egypt, 2008), 306, pls.167.

The second scene represents a rope maker as well in the tomb of Ptahhotep. He appears with a hunched back and thin limbs (Figure 15). ${ }^{73}$ Like fish gutters not all rope makers were represented hunched backs. ${ }^{74}$

70. Y. Harpur and P.J. Scremin, Chapel of Ptahhotep: Scenes Details (Oxford: Oxford Expedition to Egypt, 2008), 306, pl.167.

71. For Examples of other fish gutters see; B. Vachala, Abusir VIII: Die Reliefs aus der Ptahschepses-Mastaba in Abusir [Abusir VIII: The reliefs from the Ptahshepses-Mastaba in Abusir] (Prague: Czech Institute of Egyptology, 2004), 130-31 [A445 (1001)], 134-135 [E742 (2070)]; M.A. Roth, "A Cemetery of Palace Attendants, Including G 2084-2099, G 2230+2231, and G 2240," Giza Mastabas 6 (Boston: Museum of Fine Arts Boston/Northeastern University Press, 1995), 101, pl. 158.

72. Another hunched back old fish gutter appears in the tomb of Ti as well. See Wild, Le Tombeau de Ti. Vol.II, pl. cxxiii.

73. Y. Harpur and P.J. Scremin, Chapel of Ptahhotep: Scenes Details (Oxford: Oxford Expedition to Egypt, 2008), 307, pl. 173.

74. For examples of rope making scenes see; E. Teeter, "Techniques and Terminology of Rope-Making in Ancient Egypt," JEA 73, (1987): 71-7; A. Lucas, and J.R. Harris, Ancient Egyptian Materials and Industries (New York: Dover Publications Inc, 1999), 35-40. 


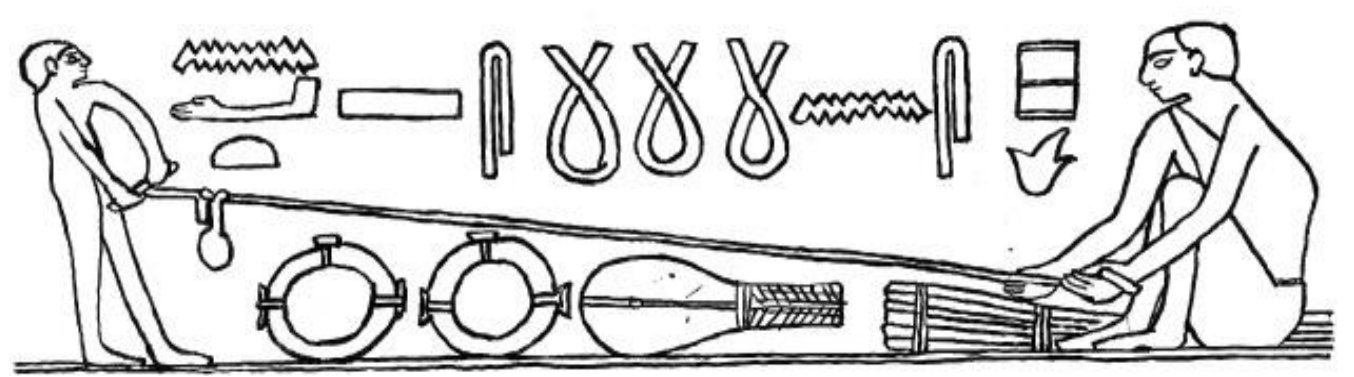

Figure 15. A Rope Maker with a Hunched Back and Thin Limbs, in the Tomb of Ptahhotep at Saqqara

Source: Y. Harpur and P.J Scremin, Chapel of Ptahhotep: Scenes Details (Reading: Oxford Expedition to Egypt, 2008), 307, pl. 173.

Comparing the two scenes; it is noticeable that though both have thin limbs and almost have the same posture, the fish gutter's hump is more stressed than in the rope maker and his head is larger and seems to be sunk into the shoulders. Perhaps because the level of fish is lower than that of the ropes; thus it needs more bending.

\section{Conclusion}

The artistic sources provide a rich legacy and documentations of physical disables position and engagement in the context of daily life activities in ancient Egypt especially in the Old Kingdom period. All classes of physical disables were likely accepted in ancient Egypt and were given a visible role in the society. Moreover their disorder was not shown as a physical handicap.

Another indication of the positive attitude toward physical deformed individuals in ancient Egypt is revealed in moral and wisdom teachings. Several high-ranking dwarfs especially from the Old Kingdom achieved important status and had lavish burial places close to the royal cemetery. Their costly tombs and statutes carved with hieroglyphs indicate their high-ranking position.

The ancient Egyptian artist was so clever in representing the individual physical deformity and he succeeded in differentiating between the portrayals of each disease. In ancient Egyptian representation being half bald with physical disability, couldn't be a favorable icon to copy, owing to the artists' commitment to idealism. It only can be supposed that the artist copied only an interesting case he noticed in fact.

The back hump was very hardly represented on wall scenes, regarding the ancient Egyptian conventional line of art, the figures were generally modeled in profile but the shoulder and torso were straight on.

Most physical disability scenes of the Old Kingdom dated back to the $4^{\text {th }}$ the $6^{\text {th }}$ Dynasties and their localities centered in Saqqara and Giza. Besides most commoners suffered from physical deformity were working as herdsmen or dog holders, an issue which still a question. 
Kings, away from Akhenaten, deities and tomb owners were commonly modeled according to the ancient Egyptian canon. They were depicted in their ideal form, with youthful, handsome and perfectly toned bodies. Few deities were fashioned in such deformed image as protective gods like God Bes.

Tomb owners and priests were occasionally shown to be suffering from sickness and deformity. Owing to minor figures such as those of workers or servants, it seems that the artist had greater freedom in rendering them. Their movements were much more flexible, dynamic and realistic. Both male and female workers were represented far from perfection, even suffering from deformity, disease, baldness or other different physical diseases.

Table 1. Survey of Physical Disability Scenes in the Old Kingdom Tombs

\begin{tabular}{|c|c|c|c|c|c|}
\hline $\begin{array}{l}\text { Type of } \\
\text { Physical } \\
\text { Disability }\end{array}$ & Tomb Owner & $\begin{array}{c}\text { Tomb } \\
\text { location }\end{array}$ & Date & $\begin{array}{c}\text { The Deformed } \\
\text { Individual Occupation }\end{array}$ & $\begin{array}{c}\text { Total } \\
\text { Appearance }\end{array}$ \\
\hline Dwarfism & $\begin{array}{l}\text { Ankhmahor, } \\
\text { king Teti's } \\
\text { vizier }\end{array}$ & Saqqara & $\begin{array}{c}6^{\text {th }} \\
\text { Dynasty }\end{array}$ & $\begin{array}{l}\text { Three pairs of dwarfs } \\
\text { were working in a } \\
\text { jewelry workshop }\end{array}$ & once \\
\hline Dwarfism & $\begin{array}{l}\text { Mereruka, } \\
\text { king Teti's } \\
\text { vizier }\end{array}$ & Saqqara & $\begin{array}{c}6^{\text {th }} \\
\text { Dynasty }\end{array}$ & $\begin{array}{c}\text { Two dwarfs were } \\
\text { working in a furniture } \\
\text { workshop }\end{array}$ & once \\
\hline Dwarfism & $\begin{array}{l}\text { Mereruka, } \\
\text { king Teti's } \\
\text { vizier }\end{array}$ & Saqqara & $\begin{array}{c}6^{\text {th }} \\
\text { Dynasty }\end{array}$ & $\begin{array}{l}\text { A dwarf dog holder } \\
\text { preceded a group of men } \\
\text { carried a palanquin chair }\end{array}$ & once \\
\hline Dwarfism & $\begin{array}{c}\text { Nefer, a } \\
\text { treasury } \\
\text { official of the } \\
\text { king }\end{array}$ & Giza & $\begin{array}{c}6^{\text {th }} \\
\text { Dynasty }\end{array}$ & $\begin{array}{c}\text { A dwarf who was } \\
\text { standing under his } \\
\text { master's chair and } \\
\text { holding a monkey on his } \\
\text { head }\end{array}$ & once \\
\hline Dwarfism & $\begin{array}{c}\text { Nuntjer, a } \\
\text { high official in } \\
\text { the } 5^{\text {th }} \\
\text { Dynasty }\end{array}$ & Giza & $\begin{array}{c}5^{\text {th }} \\
\text { Dynasty }\end{array}$ & $\begin{array}{l}\text { A female dwarf was } \\
\text { dancing with normal } \\
\text { female dancers }\end{array}$ & once \\
\hline Dwarfism & Seshemnefer & $\begin{array}{c}\text { Giza, } \\
\text { Western } \\
\text { Cemetery, } \\
\text { G } 4940\end{array}$ & $\begin{array}{c}5^{\text {th }} \\
\text { Dynasty }\end{array}$ & $\begin{array}{c}\text { A Dwarf was holding an } \\
\text { offering box over his } \\
\text { head }\end{array}$ & once \\
\hline Dwarfism & Dwarf Seneb & Giza & $\begin{array}{l}4^{\text {th }} \\
\text { Dynasty } \\
\text { and } \\
\text { begining } \\
\text { of } 5 \text { th }\end{array}$ & $\begin{array}{l}\text { Five scenes depicted } \\
\text { Seneb in the common } \\
\text { daily life activities }\end{array}$ & $\begin{array}{l}\text { The most } \\
\text { preserved } \\
\text { are five } \\
\text { scenes }\end{array}$ \\
\hline Dwarfism & $\begin{array}{l}\text { Debeheni, a } \\
\text { seal bearer }\end{array}$ & Giza & $\begin{array}{c}4^{\text {th }} \\
\text { Dynasty }\end{array}$ & $\begin{array}{c}\text { A dwarf was holding a } \\
\text { box on his shoulder }\end{array}$ & once \\
\hline Dwarfism & $\begin{array}{l}\text { Dwarf Ser- } \\
\text { Inpu }\end{array}$ & Abydos & $\begin{array}{c}1^{\text {st }} \\
\text { Dynasty }\end{array}$ & $\begin{array}{l}\text { Ser-Inpu was depicted as } \\
\text { a standing dwarf } \\
\text { accompanied with his } \\
\text { name on a stela }\end{array}$ & once \\
\hline $\begin{array}{l}\text { Backward } \\
\text { knee }\end{array}$ & Ptahhotep & Saqqara & $\begin{array}{c}5^{\text {th }} \\
\text { Dynasty }\end{array}$ & $\begin{array}{c}\text { A herder with left knee } \\
\text { backward was dragging } \\
\text { a fat bull }\end{array}$ & once \\
\hline $\begin{array}{l}\text { Backward } \\
\text { knee }\end{array}$ & $\begin{array}{l}\text { Ihy and reused } \\
\text { by Idut }\end{array}$ & Saqqara & $\begin{array}{c}5^{\text {th }} \\
\text { Dynasty }\end{array}$ & $\begin{array}{c}\text { A herder with right knee } \\
\text { backward was dragging } \\
\text { a fat bull }\end{array}$ & once \\
\hline $\begin{array}{l}\text { Backward } \\
\text { knee }\end{array}$ & Iymery & Giza & $\begin{array}{c}4^{\text {th }} \\
\text { Dynasty }\end{array}$ & $\begin{array}{c}\text { A thin herder with left } \\
\text { knee backward was } \\
\text { dragging a fat bull }\end{array}$ & once \\
\hline
\end{tabular}




\begin{tabular}{|c|c|c|c|c|c|}
\hline Polio & $\begin{array}{c}\text { Mastaba of } \\
\text { Mersyankh III }\end{array}$ & Giza & $\begin{array}{c}4^{\text {th }} \\
\text { Dynasty }\end{array}$ & $\begin{array}{l}\text { A herder with polio in } \\
\text { his left leg, was driving } \\
\text { a cow }\end{array}$ & once \\
\hline Polio & $\begin{array}{c}\text { Tomb of } \\
\text { Nikauisesi }\end{array}$ & Saqqara & $\begin{array}{c}6^{\text {th }} \\
\text { Dynasty }\end{array}$ & $\begin{array}{l}\text { A tomb owner with } \\
\text { polio in his left leg, } \\
\text { standing with an aiding } \\
\text { staff. }\end{array}$ & once \\
\hline $\begin{array}{l}\text { Hunched back } \\
\text { deformity }\end{array}$ & Seshemnefer I & Giza & $\begin{array}{c}5^{\text {th }} \\
\text { Dynasty }\end{array}$ & $\begin{array}{l}\text { A female offering bearer } \\
\text { was depicted with an } \\
\text { angular hunched back }\end{array}$ & once \\
\hline $\begin{array}{c}\text { Hunched back } \\
\text { deformity }\end{array}$ & $\mathrm{Ti}$ & Saqqara & $\begin{array}{c}5^{\text {th }} \\
\text { Dynasty }\end{array}$ & $\begin{array}{l}\text { A hunched back dog } \\
\text { holder }\end{array}$ & once \\
\hline $\begin{array}{c}\text { Hunched back } \\
\text { deformity }\end{array}$ & Ptahhotep & Saqqara & $\begin{array}{c}5^{\text {th }} \\
\text { Dynasty }\end{array}$ & $\begin{array}{l}\text { A hunched back herder } \\
\text { with round hump, was } \\
\text { feeding a bull }\end{array}$ & once \\
\hline $\begin{array}{c}\text { Hunched back } \\
\text { deformity }\end{array}$ & $\begin{array}{l}\text { Nykahem and } \\
\text { Sekhemen- } \\
\text { hathor }\end{array}$ & Saqqara & $\begin{array}{c}5^{\text {th }} \\
\text { Dynasty }\end{array}$ & $\begin{array}{l}\text { A dog holder with a } \\
\text { round hump on his back } \\
\text { and a deformed chest }\end{array}$ & once \\
\hline $\begin{array}{c}\text { Hunched back } \\
\text { deformity }\end{array}$ & $\begin{array}{c}\text { Stela of } \\
\text { Shepses-Ptah, } \\
\text { Berlin } 7779\end{array}$ & Saqqara & $\begin{array}{l}\text { Late Old } \\
\text { Kingdom }\end{array}$ & $\begin{array}{l}\text { The owner of the stela } \\
\text { was depicted standing } \\
\text { with a deformed back } \\
\text { and shoulder }\end{array}$ & twice \\
\hline $\begin{array}{c}\text { Hunched back } \\
\text { deformity }\end{array}$ & Nikauisesi & Saqqara & $\begin{array}{c}5^{\text {th }} \\
\text { Dynasty }\end{array}$ & $\begin{array}{l}\text { A dog holder with a } \\
\text { round humped back and } \\
\text { deformed chest }\end{array}$ & once \\
\hline $\begin{array}{c}\text { Hunched back } \\
\text { deformity }\end{array}$ & $\begin{array}{l}\text { Akhmerutnisut } \\
\text { Tomb G } 2184\end{array}$ & Giza & $\begin{array}{c}5^{\text {th }} \\
\text { Dynasty }\end{array}$ & $\begin{array}{c}\text { A pointed hunched back } \\
\text { man who was skinning } \\
\text { an animal hanged from a } \\
\text { tree }\end{array}$ & once \\
\hline $\begin{array}{c}\text { Hunched back } \\
\text { deformity }\end{array}$ & Khafraankh & Giza & $\begin{array}{c}4^{\text {th }} \\
\text { Dynasty }\end{array}$ & $\begin{array}{l}\text { A hunched back man } \\
\text { was cutting grain }\end{array}$ & once \\
\hline $\begin{array}{c}\text { Hunched back } \\
\text { deformity }\end{array}$ & Khunra & Giza & $\begin{array}{c}4^{\text {th }} \\
\text { Dynasty }\end{array}$ & $\begin{array}{l}\text { A hunched back boat } \\
\text { builder }\end{array}$ & once \\
\hline $\begin{array}{c}\text { Hunched back } \\
\text { deformity }\end{array}$ & Ankhwedjes & unknown & $\begin{array}{l}\text { Late Old } \\
\text { Kingdom }\end{array}$ & $\begin{array}{l}\text { A man with left arm } \\
\text { attached backward with } \\
\text { a small hump under the } \\
\text { upper part of the arm }\end{array}$ & once \\
\hline $\begin{array}{c}\text { Hunched back } \\
\text { deformity }\end{array}$ & Ptahhotep & Saqqara & $\begin{array}{c}5^{\text {th }} \\
\text { Dynasty }\end{array}$ & $\begin{array}{l}\text { An old aged fish gutter } \\
\text { with a round hunched } \\
\text { back }\end{array}$ & once \\
\hline $\begin{array}{c}\text { Hunched back } \\
\text { deformity }\end{array}$ & Ptahhotep & Saqqara & $\begin{array}{c}5^{\text {th }} \\
\text { Dynasty }\end{array}$ & $\begin{array}{l}\text { A rope maker with a } \\
\text { hunched back and thin } \\
\text { limbs }\end{array}$ & once \\
\hline
\end{tabular}

\section{Bibliography}

Ackerknecht, E. H. "Paleopathology." In Anthropology Today, edited by A.L. Kroeber, 67. Chicago: Univ. of Chicago Press, 1953.

Alonso, M. "La Stele di anx- wD.s della Glittoteca Ny Carlsberg Di Copenhagen" ["The Stele of nx-WDC of the Ny Carlsberg Glyptotek in Copenhagen, Prospective Study"]. BSÉG 21 (1997): 53, fig.12.

Cody, M. E. (Ed.). Egyptian Art, Selected Writings of Bernard V. Bothmer. Oxford: Oxford University Press, 2004.

Blackman, A.M. The Rock Tombs of Meir. Part I: The Tomb Chapel of Ukh-Hotp's son Senbi. London: The Egypt Exploration Society, 1914. 
Blackman, A.M. The Rock Tombs of Meir. Part II: The Tomb Chapel of Senbi's son Ukh-Hotp (B, No.2). London: The Egypt Exploration Society, 1915.

Chassinat, E. "Notes Prises a Mair." ["Notes Taken at Main"]. RT 22 (1911): 73-5.

Chassinat, E. "Á Propos d'un Bas-Relief du Tombeau de Senbi á Mei" ["About a BasRelief of the Tomb of Senbi á Meir"]. BIFAO 10 (1915): 169-170.

Cherpion, N. "De Quand Date La Tombe Du Nani Seneb?" [Since When Date the Tomb of Nani Seneb?"]. BIFAO 84 (1984): 34-54.

Cladet, J. "Notes Surquelques Figures Égyptienne" ["Notes on some Egyptian Figures"]. BIFAO 1 (1901): 21, fig.1.

Darby, W. J., P. Ghalioungui and L. Grivetti. Food: The Gift of Osiris Vol.1. London, UK: Academic Press, 1977.

Dasen, V. "Dwarfism in Egypt and Classical Antiquity: Iconography and Medical History." Medical History 32 (1988): 253-76, accessed January 25, 2016. doi: 10.1017/S0025727300048237.

Dasen, V. Dwarfs in Ancient Egypt and Greece. New York: Oxford University Press, 1993.

Dunham, D. and W. K. Simpson. The Mastaba of Queen Mersyankh III G.7530-7540. Boston: Museum of Fine Arts, 1974.

Dawsen, W.R. "Pygmies and Dwarfs in Ancient Egypt." JEA 24, no.2 (1938): 185.

"Disabilities." World Health Organization. Accessed July 10 2015. bit.ly/1Kf0zOm.

Duell, P. The Mastaba of Mereruka, Part II. Chicago: University of Chicago Press, 1938.

Ebbell, B. The Papyrus Ebres: The Greatest Egyptian Medical Document. Copenhagen: Levin \& Munksgaard, 1937.

Ebeid, N.I. Egyptian Medicine in the Days of the Pharaohs. Cairo: General Egyptian Book Organization, 1999.

El- Aguizy, O. "Dwarfs in Ancient Egypt." Master's thesis, Cairo University, 1970.

El- Aguizy, O. "Dwarfs and Pygmies in Ancient Egypt." ASAE 71 (1987): 53-60.

El-Kady, M. "Pataikos, an Image of a Rejuvenation Divinity." Journal of Association of Arab Universities for Tourism and Hospitality 10 (part 1), (2013): 17-28.

El Shafey, M. "Congenital Anomalies of Individuals in Ancient Egyptian Art till the End of the New Kingdom." Master's thesis, Tanta University, 1998.

Engelbach, R. "Some Remarks on Ka Statues of Abnormal Men in the Old Kingdom." ASAE 38 (1938): 285.

Erman, A. and H. Grapow. Wörterbuch der Aegyptischen Sprache (Wb III) [Dictionary of Egyptian Language (Vol III)]. Berlin: Akademie-Verlag, 19261961.

Faulkner, R.O. A Concise Dictionary of Middle Egyptian. Oxford: Griffith Institute, 1962.

Filer, J. Diseases. London: British Museum Press, 1995.

Fischer, H.G. "Notes on Sticks and Staves in Ancient Egypt." MMAJ 13 (1978): 7.

Ghalioungui, P. and Z. El- Dawakhly. Health and Healing in Ancient Egypt. Cairo: Egyptian Organization for Authorship and Translation, 1965, 19-20.

Gilbert, P. "La Date de la Figurine de Bossu" ["The date of the figurine of Bossu"]. CdE, no. 23 (1948).

Griffith, F. LI. "The Teachings of Amenophis son of Kanakht, Papyrus B.M. 10474." JEA 12, no.3/4 (Oct., 1926): 199.

Hamzaoglu, A., O. Cagatay, M. Tezer, M. Aydogan, M. Sarier and U. Talu. "Simultaneous Surgical Treatment in Conenital Scoliosis and/ or Kyphosis Associated with Intraspinal Abnormalities." SPINE 32, no. 25 (2007): 2880. 
Hart, D. M. and M. F. Macnicol. "The Knee." In Children's Orthopedics and Fractures, edited by M. Benson, J. Fixsen, M. Macnico, 495-515. New York: Springer London Dordrecht Hiedelberg, 2010.

Hawas, Z. "The Dancing Dwarf." The Ambassadors Online Magazine. The Forum for Culture and Civilization 7 (2004): 169. Accessed June 28, 2015. bit.ly/1PjojzW.

Harpur, Y. and Scremin, P.J. Chapel of Ptahhotep: Scenes details. Oxford: Oxford Expedition to Egypt, 2008.

Jonckheere, F. "Le Bossu Des Musées Royaux d'Art et d'Histoire de Bruxelles" ["The Hunchback of Royal Museum of Art and History of Brussels"]. CdE 23 (1948).

Kamal, H. Dictionary of Pharaonic Medicine. Cairo: National Publication House, 1967.

Kanawati, N. and A. McFarlane. Deshasha: The Tomb of Inti, Shedu and Others. Sydney: Australian Centre for Egyptology, 1993.

Kanawati, N. and M. Abder-Raziq. The Teti Cemetery at Saqqara: Vol.VI. The Tomb of Nikauisesi. Warminster, England: Aris and Phillips, 2000

Kanawati, N. "Tombs at Giza, Kaiemankh (G 4561) and Seshemnefer I (G 4940), Vol I". Australian Centre for Egyptology Report 16. Warminster: Aris and Phillips, 2001.

Kanawati, N. and M. Abder-Raziq. The Unis Cemetery at Saqqara, Vol.2: The Tombs of Iynefert and Ihy (reused by Idut). Oxford, UK: Aris and Phillips, 2003.

Kanawati, N. and M. Abder-Raziq. Mereruka and his Family, Part 1: The Tomb of Meryteti. Oxford, England: Aris and Phillips, 2004.

Kanawati, N. and A. Woods. Artists in the Old Kingdom: Techniques and Achievements. Cairo: Supreme Council of Antiquities Press, 2009.

Kanawati, N. and A. Woods. Beni Hassan Art and Daily Life in an Egyptian Province. Cairo: Supreme Council of Antiquities Press, 2010.

Koefoed-Petersen, O. Catalogue des Bas-Reliefs et Peintures Egyptiens [Catalog of Bas Reliefs and Egyptian Paintings]. Copenhagen: Glyptotheque ny Carlsberg, 1957.

Kozma, C. "Historical Review: Dwarfs in Ancient Egypt." American Journal of Medical Genetics, no.140A (2006): 303-311.

Lichtheim, M. Ancient Egyptian Literature, Vol. II: The New Kingdom. Berkeley: University of California Press, 1976, 149.

Loeb, W.Y. and F. J. Nunn. "Staffs as Walking Aids in Ancient Egypt and Palestine." Journal of the Royal Society of Medicine, no. 90 (1997): 453.

Lucas, A. and J.R. Harris. Ancient Egyptian Materials and Industries. New York: Dover Publications Inc, 1999.

Macramallah, R. Le Mastabad'Idout [The Mastabad'Idout]. Cairo, 1935.

Mclaughlin, M. J. and L. Florian. Disability Classification in Education: Issues and Perspective. California: Crowin Press, 2008.

Madsen, H. "EinKünstlerisches Experiment imAltenReiche" ["An artistic experiment in Old Kingdom"]. ZÄS 42 (1905): 65-66.

Mogensen, M. La Glyptotheque Ny Carlsberg, La Collection Egyptienne [The Ny Carlsberg Glyptotek, The Egyptian Collection]. Copenhagen, 1930.

Morse, D., Brothwell, D. R. and P. J. Ucko. "Tuberculosis in Ancient Egypt." American Review of Respiratory Disease 90 (1964): 524-41.

Norman de, G. D. The Mastaba of Ptah-Hotep and Akhet-Hotep at Saqqara I. London, 1900.

Nunn, J.F. Medicine in Ancient Egypt. London: British Museum Press, 1996, 78-79.

Quibell, J.E. Excavations at Saqqara, Vol. II. Cairo: IFAO, 1909.

Reeves, C. Egyptian Medicine. Buckinghamshire: Shire Publications, 1992. 
Rogers, E. M. "An Analysis of Tomb Relief Depicting Boat Construction from the Old Kingdom Period in Egypt." Master's thesis, Texas University, 1996.

Roth, M.A. "A Cemetery of Palace Attendants, Including G 2084-2099, G 2230+2231, and G 2240". Giza Mastabas 6. Boston: Museum of Fine Arts Boston/Northeastern University Press, 1995.

Ruffer, M.A. Studies in the Paleopathology of Egypt. Chicago: The University of Chicago Press, 1921.

Sigerist, H.E. A History of Medicine, Vol. I, Primitive and Archaic Medicine. New York: Oxford University Press, 1951.

Smith, D. Introduction to Special Education: Making a Difference. Boston, 2007.

Smith, W.S. A History of Egyptian Sculpture and Painting in the Old Kingdom. 2nd ed. Boston: Oxford University Press, 1949.

Solmann, H. "La Maladie d' ankh-utus" [" The disease of ankh-utus"]. BMSA 17 (1927): 61.

Stedman, L. Medical Dictionary. 24 ${ }^{\text {th }}$ ed. London: William \& Wilkins, 1982.

Steindroff, G. Das Grab des Ti, vol.II [The Grave of the Ti vol.II].Leipzig: Hinrichs, 1913.

Sullivan, R. "Deformity- A Modern Western Prejudice with Ancient Origins." Proceedings of the Royal College of Physicians Edinburgh 31, no.3 (2001): 262-6.

Teeter, E. "Techniques and Terminology of Rope-Making in Ancient Egypt." JEA 73, (1987): 71-7.

Vachala, B. Abusir VIII: Die Reliefs aus der Ptahschepses-Mastaba in Abusir [Abusir VIII: The reliefs from the Ptahshepses-Mastaba in Abusir]. Prague: Czech Institute of Egyptology, 2004.

Weeks, K.R. "The Anatomical Knowledge of the Ancient Egyptians and the Representation of the Human Figure in Egyptian Art." PhD diss., Yale University, 1970.

Weeks, K.R. Mastabas of Cemetery G 6000. Boston: Museum of Fine Arts, 1994.

Wilkinson, R. The Complete Gods and Goddesses of Ancient Egypt. London: Thames \& Hudson, 2003.

Wild, H. Le Tombeau de Ti, vol.II [The Tomb of Ti]. Cairo, 1953.

World Health Organization. International Classification of Functioning, Disability and Health (ICF). Geneva: WHO, 2001.

Wreszinski, W. Der Papyrus Ebres: Umschrift, Übersetzung Und Kommentar. Leipzig: J.C. Hinrichs, 1913. 
